\title{
1. Regulating judges: challenges, controversies and choices
}

\section{Richard Devlin and Adam Dodek}

\section{INTRODUCTION: THE CHALLENGE OF EMPOWERED JUDICIARIES}

Judges are critical actors in justice systems around the world. Despite important differences between the various legal families (civil law, common law, socialist law and religious law), the judiciary is frequently viewed as an institution of considerable significance across such legal families. Judges preside over criminal trials where the liberty and, in some jurisdictions, the lives of individuals are at stake. They interpret laws and adjudicate disputes between individuals and the state. Judges review the legality of administrative action. In some jurisdictions, they have the power to strike down laws as inconsistent with the country's Constitution. In civil cases, they may make determinations across a panorama of disputes, from divorce and child custody to personal injury and class actions to multi-billion-dollar commercial disputes. As an institution, the judiciary is often considered 'the third branch' of government alongside the legislative and executive branches. In short, judges exercise enormous power in society both as individuals and as an institution. ${ }^{1}$ We can therefore speak of judges collectively as 'empowered judiciaries'.

Broadly speaking there have been three types of responses to the emergence of empowered judiciaries. First, there are the boosters. They emphasize several key points: empowered judiciaries tend to promote development because they provide enhanced stability and predictability in the economic sphere; ${ }^{2}$ empowered judiciaries promote human and civil rights thereby enhancing human autonomy and the possibilities of improved democracy; ${ }^{3}$ and empowered judiciaries support the development of cultures of legality. ${ }^{4}$

Next, there are the sceptics. They argue that the connection between development and empowered judiciaries is much more contingent and complex than the boosters suggest. ${ }^{5}$ In addition, sceptics are concerned that empowered judiciaries are a threat to autonomy, human flourishing 
and democracy because they are unaccountable, elitist and susceptible to hubris. ${ }^{6}$

The third group consists of the pragmatists. Pragmatists accept that, for better or worse (but usually for the better), empowered judiciaries are a key institution in many societies and the challenge is to ensure that they are designed in a way that maximizes the public good. Pragmatists tend to be functionalist in their approach. While they recognize that there are important insights to be gleaned from the normative claims of both the boosters and the sceptics, pragmatists focus on the structures, institutions and processes that either are (or should be) in place to ensure that a judiciary can fulfil, but not go beyond, its proper place in the body politic. Pragmatists have produced a very rich conceptual and empirical literature ${ }^{7}$ and this book seeks to contribute to, and build upon, this work by developing and deploying a new analytical paradigm that is informed by the insights of contemporary regulation theory. ${ }^{8}$

Traditionally, most pragmatists have adopted what can be described as a dyadic paradigm to inform their analyses. That is to say, most pragmatists either explicitly argue (or implicitly suggest) that there are two key variables to be considered in any interrogation of the roles and responsibilities of a judiciary. On one side is the ideal of judicial independence and on the other is the ideal of judicial accountability. These ideals are usually constructed as being in tension, if not conflict, and most pragmatists frame their work as an attempt to find the right balance on a continuum between these two desiderata:

\section{INDEPENDENCE $\longleftrightarrow$ ACCOUNTABILITY}

This framework has generated an enormously rich, sophisticated and engaging scholarship that has been descriptive, analytical, critical and reformist. It has advanced our collective understanding of the opportunities and challenges of designing an appropriate judicial regime. ${ }^{9}$

However, despite its analytical strength, this conventional paradigm has at least three weaknesses. First, it suggests that there are only two pre-eminent normative values at stake in discussions of the judiciary. This leads many scholars to either subordinate other values to, or shoehorn them into, either independence or accountability. This has the consequence of underestimating the normative complexity of proper institutional design for a judiciary. Secondly, the conventional paradigm's embrace of a continuum tends to be a little too static and suggests a zerosum game between independence and accountability. ${ }^{10}$ This can lead to an ideological polarization in which one is forced (or perceived) to be either for or against judicial independence or accountability. Such a polarization 
can lead to unnecessary and analytically unhelpful defensiveness and intransigence. Third, the conventional continuum potentially stifles the analytical conversation when the complex nature of the design of appropriate judicial regimes requires an open dialogue.

To remedy these defects, we propose an alternative analytical paradigm that incorporates, but goes beyond, the conventional view. Hence our title, Regulating Judges: Beyond Independence and Accountability. Drawing on the insights of contemporary regulation theory, we argue that the continuum should be replaced by a regulatory pyramid that simultaneously highlights the normative and conceptual difficulties of designing and assessing an appropriate judicial regime. In the next three sections we will: (a) highlight several key themes informing contemporary regulation theory and practice; (b) propose a 'meta-level' regulatory pyramid and populate that pyramid with a number of key elements that can be used to describe, analyse and assess how any particular judiciary may be functioning; and (c) present an overview and synthesis of the contributions to this collection utilizing the pyramid.

\section{CONTEMPORARY REGULATION THEORY AND PRACTICE}

In the last three decades there has been an explosion of theoretical analyses and empirical research on regulation. This work has been driven by the insights and interactions of multiple disciplines including (but not limited to) economics, sociology, psychology, political science, law, public policy, anthropology, criminology, political economy, philosophy, history, mathematics and international relations. ${ }^{11}$ There have been regulatory investigations of almost every realm of human interaction: political, economic, social, cultural, bureaucratic, 'public' and 'private'. ${ }^{12}$ Regulatory research has been focused on micro- ${ }^{13}$ meso-,${ }^{14}$ and macro-level 15 relationships and has targeted local, ${ }^{16}$ national ${ }^{17}$ and international dynamics. ${ }^{18}$

As a result of this diversity and richness, it is not possible to provide a definition of regulation that would command the agreement of all of its interlocutors. In this sense, regulation is an 'essentially contested' concept ${ }^{19}$ and practice. However, for the purposes of this book, we adopt a working definition and suggest that there are five key themes that are particularly significant. By way of a working definition, Black et al have suggested that:

Regulation is a dynamic exercise in collective problem-solving . . the sustained and focused attempt to alter the behaviour of others according to standards or 
goals with the intention of producing a broadly defined outcome or outcomes which may involve mechanisms of standard setting, information-gathering and behaviour modification. ${ }^{20}$

Building upon this skeleton, a review of the literature suggests a number of key themes.

Regulation is an inherently normative and programmatic exercise. While there are undoubtedly difficult technical and practical aspects to every regulatory initiative, at bottom all regulation is driven by a desire to improve the public good. ${ }^{21}$ Inevitably, there are different - even competing - conceptions of what is meant by 'the public good', but there can be no avoiding the normativity of any regulatory enterprise. ${ }^{22}$ Importantly, even if there is no dispute as to the ideal values, there is usually more than one value at stake in the pursuit of the public good and these various values may be in tension or even in conflict. Regulatory interventions need to be aware of, and responsive to, these normative challenges and dilemmas.

Regulation is complex. Once upon a time 'regulation' was conceived of as an essentially prescriptive, pseudo-Austinian, phenomenon: it was the command and control model whereby one party would mandate rules and enforce compliance through sanctions. ${ }^{23}$ Regulation in this model was hierarchical, monological, deterrent-driven and 'hard'. Contemporary conceptions of regulation acknowledge that command and control prescriptions are one form of regulation, but argue that descriptively and normatively regulation is more encompassing. Because command and control approaches have their weaknesses and limitations - ineffectiveness, expensiveness, bluntness and inflexibility - the realm of regulation has been expanded to identify and endorse other forms of regulation that are more collaborative, more persuasive, more co-operative, more accommodative, more dialogical, and 'soft'. These have been variously described as 'responsive', ${ }^{24}$ 'smart', ${ }^{25}$ 'meta', ${ }^{26}$ 'really responsive', ${ }^{27}$ 'risk-based', ${ }^{28}$ 'principles-based' 29 or 'outcomes-focused'. ${ }^{30}$ Such approaches, in turn, generate an additional set of inquiries into the meaning, nature and dynamics of (non-)compliance. ${ }^{31}$

Regulatory analysis is highly contextual. Because the realms of social interaction are so diverse, and because the regulatory objectives, goals and values can be so distinct, it is neither possible nor desirable to seek universalizable regulatory analyses. ${ }^{32}$ Rather it is preferable to identify a particular realm of inquiry, articulate appropriate guiding values, and then interrogate and assess whether those values are being achieved through the prevailing structures, institutions, processes, actors and dynamics. ${ }^{33}$ Such contextualism requires us to pay attention not only to what regulators 
try to do, but also how the regulatees respond. ${ }^{34}$ Viewed in this light, regulation is a craft, a problem-solving art. ${ }^{35}$

Hybridity is the leitmotif of regulation. Because of the desire to pursue more than one value, and of the inevitable complexity and contextualism of regulation, it is often argued that hybridity is a key characteristic of contemporary regulatory practices. ${ }^{36}$ In order to appropriately respond to the interests, identities, competencies and capacities of the multiple stakeholders (both the regulators and the regulatees) the design of a regulatory architecture must be sensitive to both ends and means, outcomes and processes, and be willing to deploy a mix of regulatory approaches, mechanisms and instruments. Many regulation theorists therefore embrace and endorse regulatory frameworks which combine elements of self-regulation with prescriptive and/or accommodative regulation. The weight and prominence to be given to each form of regulation within the framework tends to be highly specific to each regulatory domain. ${ }^{37}$ This leads many analysts to propose models, heuristics and metaphors to guide their inquiries and evaluations. Matrices, ${ }^{38}$ flow-charts,${ }^{39}$ pyramids, ${ }^{40}$ rowing boats ${ }^{41}$ and even Russian dolls ${ }^{42}$ are often deployed to facilitate analysis.

Change, Flux and Innovation. Many analysts of regulation argue that because of the inevitability (and rapidity) of social, economic, political, cultural and technological changes, regulatory norms, processes and instruments must also be dynamic. ${ }^{43}$ Regulation is, therefore, always a work in progress. ${ }^{44}$ To be effective, regulatory thinking cannot be frozen in time, and regulators must be open to innovation, revision, recalibration, reconstruction and experimentation. Reflexivity and imagination are core capabilities for both regulatory actors and institutions. ${ }^{45}$

It is important to emphasize, however, that regulatory imagination and innovation are not to be understood as ends in themselves. Rather, any assessment of such changes must be directly related to the norms and values initially identified, and the outcomes desired. This is simply a reiteration of our initial observation that regulation always has an irrepressible normative underbelly.

\section{REGULATING JUDGES: A PYRAMID}

The foregoing working definition of regulation, supported by the themes of normativity, complexity, contextualism, hybridity and flux, suggest to us that the conventional dyadic framework for analysing and assessing the functioning of judiciaries could benefit from renovation and modernization. In lieu of the continuum, we propose a regulatory pyramid that is comprised of four key elements, a floor and three walls. The discussion in 
this section will develop in two stages: first we will present the regulatory pyramid at the meta level in order to demonstrate how it differs from, and is more comprehensive than, the conventional paradigm. Second we will populate the pyramid with a number of key variables that provide for possible descriptions, analyses, assessments, critiques and even potential reforms of discrete judiciaries. The following, and penultimate, section of this Introduction will then demonstrate the utility of this pyramid through synthesis of the various contributions to the book.

\section{A. The Regulatory Pyramid: A Meta-Level Analysis}

As we have indicated, we propose that an analysis of a judiciary can be helpfully constructed upon four key elements: a floor and three walls.

First, we suggest that there must be a normative foundation, a floor, for any judicial system. Without such a foundation the judicial edifice will inevitably collapse. Sometimes the components of this floor are explicit; often they are implicit. We call the foundation Values (see Figure 1.1).

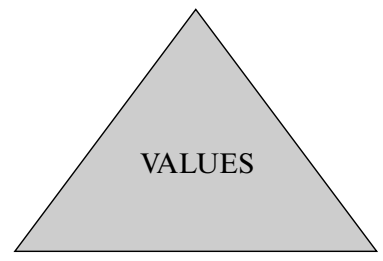

\section{Figure 1.1 Values}

At this stage of the discussion we do not specify what these values might be; we simply suggest that both normatively and analytically, they need to be there.

Second, there is the first of the three walls. We will call this Processes (see Figure 1.2).

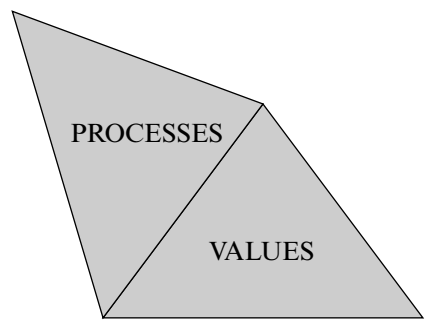

Figure 1.2 Processes 
Processes are the institutional mechanisms and procedures that are put in place to establish, maintain, channel or restrain a judiciary. They are both intimately connected with, yet distinct from, the values that lay the foundation. They are connected in that they give institutional form to the core values. They are distinct in that they are bureaucratic and, maybe, even formalistic in nature.

Raising the spectre of bureaucracy leads to the third of our pyramidal elements, and the second of our walls: Resources (see Figure 1.3).

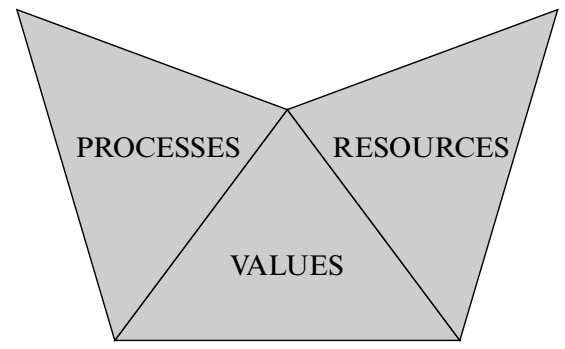

Figure 1.3 Resources

The instantiation of foundational values through the creation of bureaucracies and processes is not simply an imaginary exercise; it is a construction project and as such it requires material resources. Again, at this point, it is not necessary to identify what these resources are, or where they will come from. Rather, we simply propose that these must be factored into any analysis or assessment of how judges might be regulated.

Finally, we come to the third wall of the pyramid, Outcomes (see Figure 1.4).

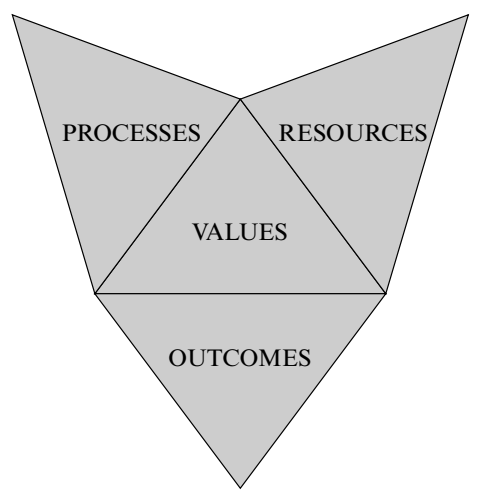

Figure 1.4 Outcomes 
The combination of values, processes and resources is designed to achieve some social good, some desirable outcome; they are the means to an end, or perhaps several ends. To the extent that a well-functioning judiciary is perceived to be a key element of a well-functioning polity, it is essential to contemplate outcomes.

Again, it is not necessary at this stage to stipulate what those outcomes might be, and they may vary from country to country, jurisdiction to jurisdiction, and legal tradition to legal tradition. However, it is important to emphasize that the outcomes must align with each of the previous elements - the foundational values, the preferred processes and the allocation of resources.

The challenge then is to bring these four meta-elements together to construct the regulatory pyramid (Figure 1.5).

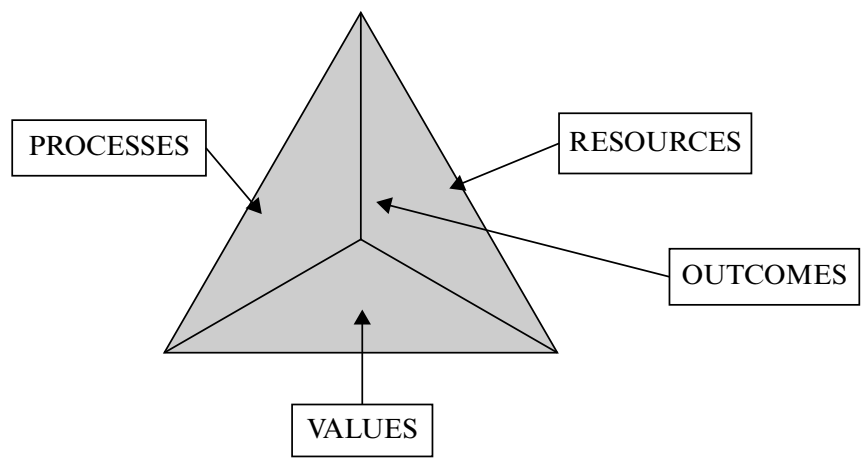

Figure 1.5 The regulatory pyramid

Now, of course, this regulatory pyramid is an ideal-type, a heuristic, a conceptual abstraction. But this abstraction is also its analytical strength. Its generality provides four variables that are potentially helpful for a description, or analysis, or assessment, or critique of all the multiple actors involved in the operationalization of a judicial system. Moreover, it is highly unlikely that any judiciary anywhere in the world would align so elegantly, or dovetail so neatly, with this model. But again such an insight can help foster analyses, inform assessments, engender critiques or initiate potential reforms. However, such engagement anticipates the second stage of our framing exercise, and it is to this that we can now turn. 


\section{B. Adding Substance/Getting Contextual: The Meso-Level Analysis}

In this subsection we go beyond the abstraction of the previous discussion to suggest some possible content for each of the four elements of the pyramid. As we begin this discussion, it is important to emphasize that we are not endorsing any particular content; we are simply suggesting potential content which various jurisdictions may seek to pursue in their regulatory regime for the judiciary. They are also likely to vary with time, space, culture and context. But if we can identify such content, then it becomes a benchmark for assessment and evaluation, which is the aspiration for all of those who have an interest in this field.

\section{i. Values}

At this stage it is important to identify the values that a community might expect to guide and govern a judiciary. ${ }^{46}$ This is potentially quite difficult because values are often implicit, intuitive and taken for granted. Then, when they are articulated, values are open to contestation. Even worse, they may reveal contradictory aspirations and normative visions. But it is hard work that must be done - if we do not know what we value, how can we know what we are regulating for?

Thus, at this point, we hypothesize that the following six values might lay the foundation for a regulatory regime for judges:

(1) Impartiality: decision making that is free from personal, social, cultural, economic or institutional bias, and which fairly assesses the rights and interests of the parties involved.

(2) Independence: personal and institutional freedom from state and non-state actors in order to make autonomous judgment possible.

(3) Accountability: the commitment to ensure that the values of independence and impartiality are appropriately deployed in the public interest, rather than the interest of judges themselves.

(4) Representativeness: the composition of the judiciary is broadly inclusive of the diversity of the larger population, particularly on the variables of gender, race, class and disability.

(5) Transparency: the commitment to openness and candour.

(6) Efficiency: the aspiration that social and personal investments in the judiciary and judicial processes are cost-effective.

We recognize that there are other elements or variables that are deserving of further consideration. In the penultimate section of this Introduction, we reflect upon these variables in light of each of the 19 case studies that this book offers. 


\section{ii. Processes}

If values are the floor, then processes are one of the walls of the pyramid and, as such, are intimately connected with values. As we have suggested, they are the institutional mechanisms and procedures put in place to establish, maintain, channel or corral a judiciary. The processes are likely to include:

(1) institutional relations (eg constitutional, conventional or statutory) with the other state institutions (eg executive, legislature, Crown, political and religious authorities, etc);

(2) recruitment and appointment processes;

(3) training and continuing education;

(4) appellate mechanisms;

(5) ethical assistance programmes and networks;

(6) complaints and discipline processes;

(7) relations with the public;

(8) relations with media;

(9) judicial immunity/liability; and

(10) performance evaluation.

\section{iii. Resources}

Because the judiciary is an institution, a bureaucracy, it inevitably requires resources, and the nature and extent of those resources is closely tied to the values we espouse, the processes we endorse and the outcomes we anticipate. Consequently some of the issues that merit attention include:

(1) court budgets;

(2) numbers of judges, part-time and full-time, per capita;

(3) salaries and pensions of judges;

(4) physical infrastructure;

(5) support staff;

(6) technological needs/supports; and

(7) security.

\section{iv. Outcomes}

Values, processes and resources are all designed to achieve desired outcomes. Although these might vary from jurisdiction to jurisdiction, we suggest that one potentially generalizable outcome would be public confidence in the judiciary.

In sum, our regulatory pyramid is as shown in Figure 1.6. 


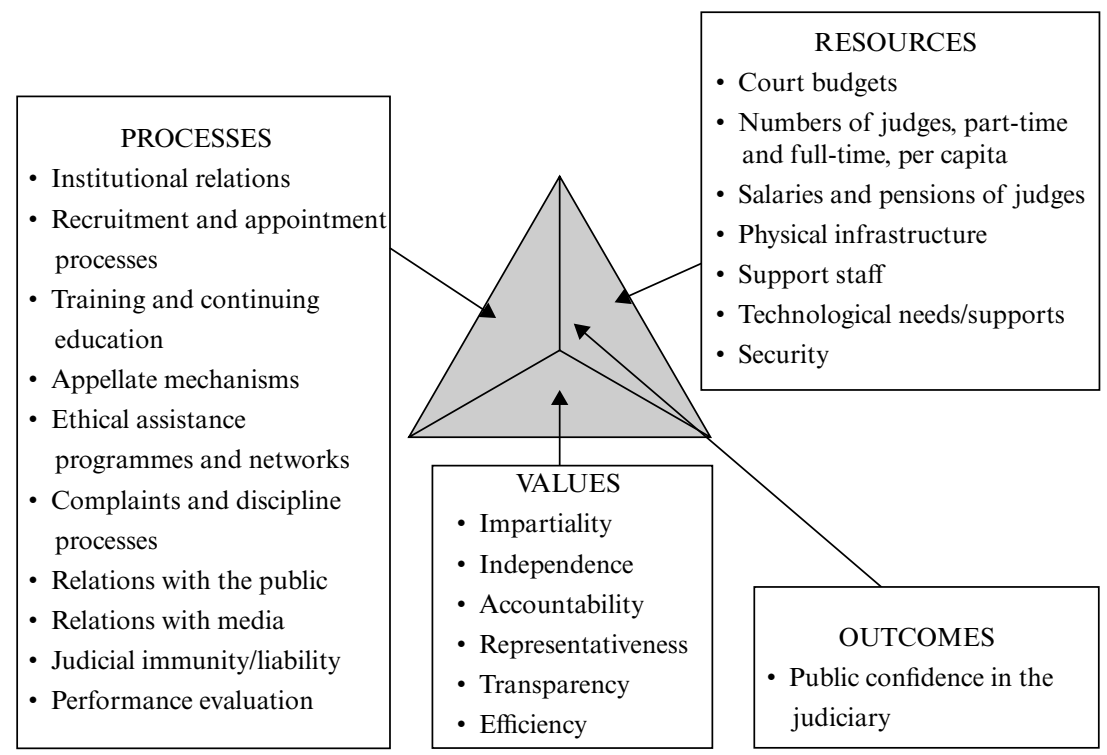

Figure 1.6 The regulatory pyramid and its components

\section{DEPLOYING THE PYRAMID: THE CASE STUDIES}

\section{A. The Contributors - Overview}

In conceptualizing this book, we invited scholars from 19 jurisdictions to reflect upon what have been, or currently are, some of the most salient issues in their chosen jurisdiction when it comes to the challenges of regulating judges. We intentionally selected a mix of scholars from a variety of jurisdictions in order to determine if the pyramid had any analytic resonance. Readers may inevitably ask why a particular country was not included. The aim of this project was not to create an encyclopedia but rather a manageable collection of essays from diverse jurisdictions. All continents are represented in this collection and all major legal systems. We are common law scholars and this collection has a heavy dose of common law jurisdictions. We have endeavoured to include representative civil law jurisdictions (Brazil, Croatia, Germany, Italy, Portugal and Russia), mixed systems (India, Israel, Japan, Malaysia, Singapore and South Africa) and other systems (ie China: socialist). ${ }^{47}$ We also deliberately 
selected a diversity of scholars in terms of seniority, gender and race in order to bring as many voices to the conversation as might be manageable within the confines of a single edited collection..$^{48}$ Furthermore, in order to ensure diversity, creativity and freshness of voice, we did not insist that contributors adopt our pyramid as some sort of scientific formula to be single-mindedly applied. Rather, we encouraged them to use it as potential scaffolding, or as a point of departure, for their own narratives of judicial regulation. As a consequence, some authors have embraced the pyramid wholeheartedly and applied its components broadly (Campbell and $\mathrm{Fu}$, Corder, Dodek and Devlin, Gee, Oliviera, Trochev). Others have focused on selected aspects of the pyramid (Appleby and Le Mire, Akšamović, Fabri, Fennelly, Puthucherril, Simões, Chan, Wolf and Klass, Zer-Gutman), and yet others have chosen to undertake in-depth analyses of several issues that can be located within the pyramid (Cravens, Dare, Neo and Whalen-Bridge, Whalen-Bridge and Neo). While some readers might find that this openness to diversity undercuts the scientific rigour of the project, we believe it enhances the authenticity of the contributions and the particularity of the challenges of judicial regulation. Moreover, this approach has enabled country experts to focus on the approach that best suits their ability to present a story about their national judiciary. As a result, we believe that this has facilitated the work of our contributors, rather than boxed them into our chosen paradigm. Indeed, some contributors implicitly or explicitly challenge aspects of our regulatory pyramid (Dare, Gee, Whalen-Bridge and Neo). Rather than undermining the project, we believe that the expression of such scepticism is healthy and promotes the goal of this project, which is to open up the conversation about the regulation of judges.

\section{B. The Contributors - Synthesis}

In this section, we will locate some of the insights generated by the contributors in the context of the various components of the regulatory pyramid.

\section{i. Values}

All of the contributors agree that regulating judges, like all forms of regulation, ${ }^{49}$ is an inescapably normative project. Each author has identified how certain values - sometimes explicitly, sometimes implicitly - inform the design and practice of the regulatory systems in their respective jurisdictions. Collectively, they also indicate that such values are contested, deeply contextual, in need of considered calibration, and in a continuous state of flux. They also concur that no one value should trump all others. 
Impartiality Somewhat surprisingly, our contributors do not give impartiality as much explicit attention as we would have thought. There may be several reasons for this. First, they may see independence and impartiality as synonymous. Second, they may conceptualize impartiality as more of an 'outcome' than a 'value' as some have suggested to us at various times. Or third, they might assume that impartiality is so obvious that it does not require explicit analysis. Having said this, several commentators do expressly identify concerns with the impartiality of their judges (China, Croatia, India, Japan, Malaysia, Portugal, Russia, United States) while others claim the opposite (England and Wales, Germany, Ireland, New Zealand, Singapore).

Moreover, as we will discuss below under the rubric of processes, several regulatory mechanisms are explicitly focused on enhancing impartiality (appointment processes, educational programmes, appellate mechanisms, ethical assistance initiatives, discipline mechanisms, performance assessments and judicial liability) and some of these do garner extensive analysis among the contributors.

However, there are several discussions where impartiality is identified as not being a priority value and is subordinated to other political, social and cultural norms (China, Italy, Japan, Russia, United States).

Independence Unsurprisingly, almost all of the contributors identify independence as a core judicial value. Whether we are discussing well-established democracies (Australia, Canada, England and Wales, Germany, India, Ireland, Israel, Italy, Japan, New Zealand, Portugal, United States), emerging democracies (Brazil, Croatia, Malaysia, Singapore, South Africa) or even non-democracies (China, Russia), independence is recognized as a vital characteristic of any defensible judicial regime. Even in jurisdictions where one would think that independence is impossible, such as China, a 'nuanced conception of independence' is still in play. Similarly in Russia, there are several significant indicators of judicial independence, not only in constitutional theory, but also in judicial practice.

The authors also make several other key points. First, independence is identified as having multiple dimensions. The core, of course, is the independence of the individual judge. Here the ideal is that each judge is free to determine the outcome of a case uncontaminated by extraneous influence, either from inside the judiciary or from without. Then there is the independence of the judiciary as an institution. This tends to focus on the separation of powers thesis, suggesting that the judiciary as a collective be understood as a distinct and free-standing institution. Finally, there is administrative independence, the idea that as a bureaucracy the judiciary 
should be master of its own house, with the capacity and resources to pursue its obligations in the manner in which it sees fit. The case studies demonstrate that from jurisdiction to jurisdiction, the balance of these three conceptions of independence varies enormously, and that they can shift over time.

Second, the legal status or pedigree of the value of independence varies considerably. In some jurisdictions it is given explicit constitutional status (Brazil, Croatia, Germany, India, Ireland, Italy, Japan, Malaysia, Portugal, Russia, Singapore, South Africa); in others it is more of a constitutional convention or norm (Australia, Canada, England and Wales, New Zealand, United States); in others it manifests in legislation (Israel); and in yet others it is formally absent (China). Such divergences are significant for two reasons: they illustrate once again the highly context-specific nature of our values; and they also highlight that there is no necessary connection between formal legal pedigree and the materialization of such values on the ground.

Third, the chapters demonstrate that without exception, judicial independence is vulnerable to challenges by other social actors. In all jurisdictions the judiciary is identified as a key political institution and this inevitably tempts governments and other powerful actors in the community, and even other judges, to seek to have influence over the judiciary. We will elaborate further on this in our discussions of processes.

Fourth, while all the contributors concur that independence is crucial, a significant number (Australia, Brazil, Canada, Croatia, India, Ireland, Israel, Italy, New Zealand, Russia, United States) also provide examples of how judges have deployed (or have sought to invoke) independence in a manner that is resistant to reform and seems to be more in the interests of themselves than the promotion of a public good. The result can be an undermining of public confidence in the judiciary.

Accountability Once again it is not surprising to see accountability as an important value, given that this has been one of the poles in the traditional dyadic analytical framework. As a manifestation of the "who guards the guardians?' conundrum, the chapters in this book suggest that there are several mechanisms available to ensure that judges do not arrogate to themselves excessive authority and power. ${ }^{50}$ These might include constitutional modifications, legislative/executive interventions, discipline mechanisms, elections, educational initiatives, judicial liability, media scrutiny and budgetary controls, among others. Some of these mechanisms are 'hard' regulation; others are 'soft'. The acceptability, suitability and effectiveness of such mechanisms are highly context dependent.

Furthermore, there are a number of regulatory failures where it seems that accountability mechanisms have been less than effective (Canada, 
Croatia, India, Italy, Russia, United States). However, one's acknowledgement and assessment of the degree of such failures will be dependent on whether one is more of a booster, sceptic or pragmatist, and one's own judgment of how to balance the multiple values at stake in designing an appropriate regulatory regime.

Representativeness Representativeness is a much more contested value than impartiality, independence or accountability. For some, representativeness is a vital value in that it seeks to demonstrate that the judiciary is broadly reflective of the larger community and that, in turn, enhances its capacity for impartiality and fosters greater public confidence. Others, however, believe that representativeness is antithetical to independence and indeed an assault on impartiality.

Not all of the contributors have addressed the value of representativeness. Among those who do (England and Wales, Italy, Japan, Portugal) representation refers to the professional diversity of the legal profession (barristers, solicitors, academics); for others it may relate to the geographic diversity of a jurisdiction (Canada); for others it might relate to gendered, racialized or other forms of identity (Australia, England and Wales, Canada, Germany, Ireland, South Africa).

Transparency Transparency is closely connected to the values of accountability and efficiency, but in recent decades it has come to be identified as a significant value for any system that aspires to good governance. ${ }^{51}$ Once again, not all of the contributors address transparency directly. However, for those who do, it is identified as a major issue for judicial regulation (Australia, Canada, England and Wales, Germany, India, Ireland, Israel, Italy, New Zealand, Russia, United States). In most jurisdictions the judiciary is an elite and privileged group which exercises significant social and political power. But in a number of key domains there seems to be excessive secrecy, for example in appointments (Australia, Canada, China, Germany, India, New Zealand, Russia, United States), complaints and discipline (Australia, Russia), ethical guidance, education and evaluation. However, in other jurisdictions, there have been significant moves towards much greater transparency (England and Wales, Ireland and Italy).

One particularly interesting (and obviously controversial) development is the recent innovation in two jurisdictions that judges be required to make public their annual judicial household income (Russia, South Africa). In India, judges are obliged to provide asset declarations under the Right to Information Act. The United States has required annual financial disclosure from all federal judges, including those on the Supreme Court, for many years. ${ }^{52}$ 
Efficiency The value of efficiency attracts a great deal of interest from the contributors. Traditionally, concerns about efficiency have been seen to be a sub-element of accountability, but its prominence in this volume suggests that it is important to consider it as a free-standing variable.

The epitome of the importance of this regulatory value is probably the establishment in 2002 of the European Commission for the Efficiency of Justice (CEPEJ). ${ }^{53}$ According to its founding statute, the functions of the CEPEJ are to:

(a) examine the results achieved by the different judicial systems by using among other things, common statistical criteria and means of evaluation, (b) define problems and areas for possible improvements and exchange views on the functioning of judicial systems, (c) identify concrete ways to improve the measuring and functioning of the judicial systems of the member states having regard to their specific needs.

The statute continues that the CEPEJ shall fulfil these tasks, for instance, by:

(a) identifying and developing indicators, collecting and analyzing quantitative and qualitative figures, and defining measures and means of evaluation, and (b) drawing up reports, statistics, best practice surveys, guidelines, action plans, opinions and general comments. ${ }^{54}$

While the mandate of the CEPEJ includes more than just judges, the efficiency and effectiveness of judges lie at the core of a significant number of the chapters of the biannual reports which are produced by the CEPEJ. ${ }^{55}$

Efficiency has also been a core concern for many of the contributors to this collection and collectively they suggest that this is a value that has been assuming significantly greater prominence in the last few decades (Canada, China, Croatia, England and Wales, Germany, India, Ireland, Italy, Portugal, Russia, Singapore). ${ }^{56}$ In Brazil, 'efficiency' has even been given constitutional status. The consensus seems to be that in every jurisdiction increased judicial efficiency is an uphill battle.

Other values While most of the contributors to this book concur that the foregoing values are some of the more pertinent values that should inform an assessment of the regulatory regime for judges, several contributors emphasize that it is important to pay close attention to other more jurisdictionally specific values. In Canada it is federalism. In Israel they are fairness, due process and access to justice. In India they are Dharma and social justice. In China they include $l i$, face and guanxi in the pursuit 
of social harmony and economic growth. In Japan it is a deep-seated commitment to conservatism. In Germany, it is a commitment to defensive democracy and the protection of human rights in response to the catastrophe of Nazism. In Singapore, it is national pride in its reputation for transcending corruption. In Russia, it is loyalty to the relevant power holders whether they be local, regional or national. In the United States, they are the values of democratic accountability through the ballot box and the constitutional protection of free speech. In South Africa, it is 'transformative egalitarianism'.

\section{ii. Processes}

Processes are the focus of the vast majority of our contributors. This is understandable because they are all lawyers, and lawyers are strongly attracted to processes. But their discussions of the processes reveal the values at stake, the outcomes sought and the resource issues involved.

Institutional relations All the contributors acknowledge that discussion of the institutional relationships with other government (and in some cases non-government) actors is essential to an understanding of how judges are regulated. The key institutions tend to be the executive, the legislature and the bureaucracy. Some authors focus on the constitutional nature of the relationships (Brazil, Canada, Croatia, England and Wales, Germany, India, Russia, South Africa); others (and even sometimes the same authors) focus on the conventions that have developed to inform such relationships (Canada, England and Wales, Ireland, Japan, New Zealand, Russia); others discuss the statutory regimes governing the relationships (Australia, Israel, Italy, Malaysia, United States); while others address the policy-level dynamics of the relationships (China, England and Wales, Russia, Singapore). Increasingly, international/regional organizations also seem to be having a regulatory impact on some national judiciaries (Croatia, Portugal, Russia, Singapore).

Collectively the chapters reveal that there is often tension - indeed even outright conflict and hostility - between the judiciary and the other institutions. Sometimes these challenges are structural (Australia, Brazil, Croatia, India, Ireland, Israel, Italy, Portugal, Russia, South Africa, United States), but on other occasions they seem to have a personal dimension (Australia, Canada, China, India, Israel). Occasionally, these relationships are relatively smooth (Germany, New Zealand) but only if the judiciary is compliant (Japan).

Recruitment and appointment Those who are familiar with the civilian tradition of 'career judges' intuitively recognize that appointment 
processes are inherently regulatory in nature because of the openly competitive and (supposedly) merit-based nature of the appointment and promotion regimes (Brazil, China, Croatia, Italy, Germany, Portugal, Russia). However, not all common lawyers who are familiar with a regime of 'recognition judges' (ie those appointed from the ranks of lawyers) recognize the regulatory nature of the process. In fact, we would argue that recruitment and appointment processes are perhaps the most powerful regulatory instruments because they are ex ante in nature; they filter in and they filter out. We will explain by way of analogy.

In many jurisdictions we talk about 'admission to the practice of law' and in so doing recognize that this is a privilege not a right, a privilege that is conferred on only some people who are suitably qualified based upon some specified criteria. This is hard regulation - regulation as gatekeeping, regulation as command and control - and we recognize it as a very powerful form of regulation. ${ }^{57}$ The recruitment and appointment of judges is similar and can be conceptualized as 'admission to the practice of judging'. It too is a privilege and not a right, one that is conferred on a very small number of people who are assessed to be suitably qualified based on some very particular criteria. This too is hard regulation - command and control, gatekeeping - a very powerful form of regulation. In fact, it is the most significant form of regulation because all the others are only potentially triggered after appointment. Therefore judicial appointment is judicial regulation par excellence.

Several insights emerge from our contributors on the theme of recruitment and appointments. First there are a variety of regulatory regimes: career approaches (Brazil, China, Croatia, Germany, Italy, Japan, Portugal, Russia); election approaches (Japan, United States); and recognition approaches (Australia, Canada, England and Wales, India, Ireland, Israel, New Zealand, Singapore, South Africa).

Second, in every jurisdiction and regardless of which appointment process is adopted, there is controversy that politics (whether the everyday politics that exist within any institution or partisan politics or both) contaminate the process, potentially challenging the values of independence, impartiality, transparency, representativeness and even efficiency. Judicial appointments are seen as a glittering political prize, and the power to control such appointments is highly coveted by legislators, executives, senior judges, bureaucrats and other powerful social actors. Even in jurisdictions that have tried to eliminate political influences, for example through the use of Judicial Appointments Commissions, problems remain.

Third, and closely connected, while there are formal processes in place in most jurisdictions, informal considerations, connections, norms and networks are pervasive. Fourth, similar concerns are reproduced, indeed 
intensified, in the context of judicial promotions/elevations where often there is even less transparency.

Training and continuing education The training and continuing education of judges is a vitally important form of regulation because it is designed to ensure that judges are competent, thereby enhancing public confidence. Depending on their content, such educational programmes can also seek to advance or reinforce the values of impartiality, independence, accountability and even efficiency.

Only a limited number of contributors address this important issue, ${ }^{58}$ but they suggest several key insights. First, just as with appointments, diversity is the key motif. Broadly speaking, career judges get extensive pre-appointment training (Brazil, China, Croatia, Germany, Italy, Japan, Portugal, Russia) whereas in recognition judiciaries it is minimal (Canada, England and Wales, India, Ireland, New Zealand, United States), although there are signs that this might be changing (Australia, England and Wales, Singapore). Second, and connected to the first point and depending on the system, education and training can be considered either as hard or soft regulation, and this in part will also depend upon whether such programmes are mandatory or optional. Third, again depending on the content (and also who is empowered to design and deliver such programmes), there is the need to consider how political (both institutional and partisan) considerations might be brought to bear and how they implicate the values of impartiality, independence, transparency, efficiency and accountability.

Finally, a number of systems have been attempting to improve their continuing education programmes in recent years (Australia, China, Croatia, England and Wales, India, Malaysia, Singapore, South Africa) but the key question remains as to how to assess the effectiveness of such initiatives.

Appellate mechanisms The power of an appellate court to either confirm or reverse the decision of a lower court judge is a vitally important regulatory mechanism. It is an obvious example of hard regulation. It is also a form of judicial self-regulation. Appellate overruling might be seen as an infringement on the independence of an individual judge, but it is justified on the basis of accountability, transparency and perhaps efficiency. In some jurisdictions we hear of lower-level judges 'appeal proofing' their decisions.

Only some of the contributors address appellate review as a regulatory instrument. This is surprising because judges tend to point to appellate mechanisms as the primary exemplar of accountability. However, as 
demonstrated in this Introduction and by the contributions to this book, it is not the only form of accountability, nor necessarily the strongest or most efficient process to facilitate accountability. Appellate review is directly related to public confidence; a mechanism needs to be in place to ensure that an aggrieved party can seek a considered second opinion. However, there is a manifest concern that appeal mechanisms can be abused, especially through delay tactics, and this can undermine public confidence in the system, especially where there are concerns about inequality between the parties (Brazil, Croatia, India).

Ethical assistance programmes and networks In most jurisdictions explicit analysis and discussion of judicial ethics is a relatively recent phenomenon, perhaps because of the historic ideal/presumption that judges are impartial and independent. ${ }^{59}$ However, with an expanding emphasis on accountability and transparency, increasing attention has been paid to this sphere. It is also closely connected to the enhancement of public confidence in the integrity and impartiality of the judiciary. As such, it is an important form of regulation.

Once again our contributors shed light on several key regulatory questions. The first is whether it is necessary for judges to be subject to a code of conduct. In most jurisdictions covered in this book they are, but in some they are not (Canada, Germany, United States). This in turn requires us to consider the possible functions of a code of conduct - self-regulation, assertion, public confidence, governmental control - and the relative desirability of each of these (Malaysia). The third question is whether such a code should be published and publicly available or only accessible to the judges themselves (Singapore). The fourth is whether a code should be binding (and therefore potentially part of a discipline mechanism) or simply hortatory (and therefore only a guideline for suitable behaviour) (Canada, Malaysia). The fifth is whether a code should only regulate judicial behaviour, or whether it should also regulate extra-judicial/ private behaviour. A sixth is who should decide the content of such a code. Should it be the judges themselves and/or others, and if so whom (Israel, Malaysia, Russia, Singapore, United States)? All of these issues are really a manifestation of a larger debate about whether a code of conduct should be hard or soft regulation. They also inevitably implicate the various values at stake, as well as public confidence concerns.

Furthermore, several contributors also discuss the regulatory significance of 'ethical assistance committees'. In most jurisdictions, judges usually have informal conversations with judicial colleagues when they experience an ethical dilemma. Often this will be with a senior colleague. This is an example of soft/informal regulation. However, several jurisdictions have 
created committees to which a judge can make an inquiry seeking advice on how to respond to an ethical dilemma (Canada, Israel, United States). The advice of such committees can be an important form of regulation because, although it is not binding, it can have a very significant impact on the decision making of the judge in question. But this in turn raises the regulatory questions of whether such advice should be made available to other judges (and if so, under what conditions?) (Canada, United States) or even to the general public (and again, if so, and under what conditions?) (Israel, United States). Such debates are informed by the values of independence, accountability, transparency, efficiency, the challenge of resources, and the desire to promote public confidence in the judiciary.

Complaints and discipline mechanisms Complaints and discipline mechanisms are often the first thing that comes to mind when one couples 'regulation' with 'judges'. This is mostly because complaints/discipline dovetails very nicely with traditional command and control conceptions of regulation. But at this point we want to reiterate that complaints and discipline mechanisms are only one of the multiple forms of regulation experienced by judges. While complaints/discipline may be high profile and high drama, because it is an ex post form of regulation, its actual impact on judicial behaviour may be less than other forms of regulation.

The authors offer a number of contributions to the understanding of complaints and discipline processes for judges. First, once again they suggest a multiplicity of possible systems. Some are self-regulatory in nature (Australia, Brazil, Canada, Croatia, Ireland, Italy, New Zealand, Russia), others manifest external regulation (China) while others are coregulatory in nature (India, Israel).

Second, and again connected to the first point, they illustrate that complaints/discipline highlights the challenges of calibrating the values of impartiality, independence, transparency, accountability and efficiency. The case studies demonstrate that there is no necessary connection between one form of regulation and any particular value; the connections are contingent on a complex mix of variables.

Third, complaints/discipline is often a flashpoint between the judiciary and the other branches of government or other powerful social actors. If the politics of a particular disciplinary action are not always immediately obvious, they are usually not far below the surface.

Fourth, the design and appropriate enforcement of complaints and discipline mechanisms are vital aspects of promoting public confidence in the judiciary. In this regard, there are significant concerns about both the transparency (Australia, Canada, India, Ireland, Italy) and efficiency (Canada, India, Italy) of such systems. 
Fifth, given all the foregoing, complaints and discipline processes have been a particularly fertile domain for reforms in a number of jurisdictions (Canada, England and Wales, India, Ireland, Italy, South Africa), although whether such initiatives are successful remains unresolved.

Relations with the public Traditionally in many societies judges have been set apart from the general public. In both their public and private lives they were often encouraged - or they chose or were required - to lead a cloistered existence. Though rarely categorized as such, such culturally constructed norms are in fact an extremely potent form of regulation, constituting the identity and relations not only of the judge but also potentially his or her family members. This construct was justified on the basis of impartiality and independence, and the presumption that it would contribute to public confidence.

However, as the contributors demonstrate, with increasing emphasis on transparency and representativeness, judges in some jurisdictions have been stepping out of their traditionally cloistered existence to engage more actively with their communities (Australia, Canada, South Africa). It is thought that demonstrating the human face of the judiciary is more effective in promoting public confidence than institutionalized aloofness.

Relations with the media In the modern world the media are essential fora of social interaction. Traditionally, once again driven by the prioritization of independence, the preferred position has been media avoidance. However, in many jurisdictions that is no longer a realistic option. ${ }^{60}$

The media might well be understood as a form of 'soft regulation'. While they have no direct authority over judges, the presence of media is an important mechanism of transparency and accountability. In the United States, for example, there has been extensive media coverage of potential bias by members of the Supreme Court. In both Russia and South Africa, there has been considerable media attention on the judiciary. The media may also influence judges' decision making. In the United States, there has been much discussion of the so-called 'Greenhouse effect', named after Linda Greenhouse, the New York Times long-serving Supreme Court reporter and analyst. The 'Greenhouse effect' refers to the leftward shift of conservative justices in order to curry favour with the liberal media. ${ }^{61}$

The importance of media relations is highlighted by the fact that in several jurisdictions, courts have increasingly been resorting to the services of 'judicial liaison officers' (Australia, Canada) and broadcasting (some of) their proceedings (Brazil, Canada, Russia, United States). 
Judicial immunity/liability Another potentially important regulatory mechanism is to hold judges liable for wrong decisions. Although few of our contributors directly address this question, it is important. Legal liability for conduct that harms another is a key aspect of any legal system, whether it relates to driving mistakes, medical mistakes, environmental mistakes or whatever. It is a key instrument of accountability.

Traditionally, it has been argued that judicial liability is incompatible with judicial independence, and that the better regime is one that embraces absolute judicial immunity. ${ }^{62}$ This might be a persuasive argument if other regulatory mechanisms - such as complaints and discipline - are effective. However, as many of the chapters in this collection demonstrate, this is not the case. Therefore, it might well be worth asking whether it is necessary to have a system of absolute judicial immunity. Might it not be worthwhile considering a system of 'qualified judicial immunity', a system that is in fact in place in some civilian systems (China, Italy, Portugal), which would more finely calibrate the virtues of impartiality, independence, transparency and accountability? ${ }^{63}$

Performance evaluation Although not all of the contributors focus on performance evaluation, it can be a vitally important aspect of any regulatory system for judges. ${ }^{64}$ In civilian systems where there is a career judiciary, there are well-established regimes of evaluation primarily designed to assess the suitability of candidates for admission and then promotion through the judicial ranks (Brazil, China, Croatia, Germany, Italy, Japan, Portugal, Russia). ${ }^{65}$ Such systems are very much concerned with the values of impartiality, independence, transparency, accountability and efficiency. ${ }^{66}$ They are also designed to help reinforce public confidence, especially in terms of competence. ${ }^{67}$ Whether they succeed in these aspirations is a difficult question (Croatia, Italy).

However in some 'recognition judiciaries' (Canada) the idea of evaluation has been decidedly controversial. The concern, mostly articulated by judges, is that it will be a threat to the independence of individual judges. ${ }^{68}$ However, there have been developments in some recognition judiciaries (United States, ${ }^{69}$ Australia $^{70}$ ) and it is on the agenda in others (England and Wales).

\section{iii. Resources}

Traditionally, the literature on resources has been framed as a subfield: 'court administration'. ${ }^{71}$ While this approach has been useful, ${ }^{72}$ it may have the unintended consequence of marginalizing some key questions about the regulation of judges, by suggesting that this is essentially a bureaucratic/technical/managerialist concern. Our regulatory pyramid 
suggests that, in fact, analyses of resources are an essential component of any assessment of a judiciary. Resources - their quantity, quality and allocation - are intimately connected to the values we espouse, the processes we establish and the outcomes we desire. Indeed, the issues of resources often underpin many of the challenges and controversies of regulation. This has been demonstrated by the contributors on several fronts.

Court budgets The chapters illustrate that court budgets have been an especially thorny issue in many jurisdictions. Not only is there the obvious question of what percentage of a nation's GDP should be allocated to the judiciary, but also who should control and manage it.

This has led to significant tensions between judiciaries and other branches of government and required a variety of forms of regulation ranging from external regulation, through co-regulation to self-regulation (Australia, Brazil, Canada, Croatia, England and Wales, Ireland, Italy, Portugal, Russia). It also raises questions of independence, transparency, accountability and efficiency and has a direct impact on whether the public can have confidence in its judiciary.

The case studies also suggest that in some jurisdictions there has been an increase in the resources being allocated to judiciaries (China, Croatia, Russia) while in others there have been decreases (Australia, Canada, England and Wales, Ireland).

Numbers of judges It will be difficult for the general public to have confidence in its judiciary if there are not enough judges to respond to public expectations, and sufficient numbers to deliver justice in a timely manner. However, the chapters indicate that this is a difficult issue to address. The idea that this can be assessed through some ratio of judges to general population ignores the existence of differences in legal cultures. Some cultures are more litigation oriented and therefore expect or require greater numbers of judges (United States, India, Ireland, Israel); others are litigation averse (China, Japan) and therefore require or expect lesser numbers of judges.

There is also the complex question of the suitable proportionality of judges within the system, between 'superior and inferior' judges. The problem is that, given the politics within the judiciary, there may be more than enough superior court judges but an under-supply of inferior judges, the 'coalface judges', thereby undermining public confidence (Brazil).

Salaries and pensions Salaries and pensions are a key regulatory issue for several reasons. First and most obviously, they have an impact on the 
quality of judges. In jurisdictions where judges are insufficiently remunerated, there are problems of both recruitment and retention (China).

Second, adequate salaries are said to be essential to ensure both independence and impartiality and as a bulwark against corruption and bribery (China, India, Italy, Russia).

Third, there are wide variations in how judges are compensated. It is not just the fact that some countries can afford and choose to pay their judges more than others; it is also the issue of how well they are compensated in proportion to the general population. In some jurisdictions they are among the highest earners (Brazil, Canada, England and Wales, Ireland, Italy); in others they are in the middle (Croatia, Germany, United States); while in others, they are relatively poorly paid (China).

Fourth, there is also the topic of salary security. The value of independence has sometimes been deployed to assert that a judge's salary cannot be reduced or frozen by governments, and in fact has been elevated to constitutional status in some jurisdictions (Canada, Ireland, Italy, South Africa). However, in other jurisdictions, drawing on the principles of accountability and efficiency, such reductions are defensible so long as they are not particularly targeted at judges and part of other necessary austerity measures (Ireland). One regulatory response that has been adopted in several jurisdictions is to refer such matters to some form of 'independent tribunal' (Australia, Canada).

Physical infrastructure Physical infrastructure is closely connected to the issue of court budgets, as previously discussed. If a judiciary does not have adequate physical infrastructure, it may be difficult to recruit suitable candidates or to deliver adequate dispute resolution services. Both of these weaknesses can contribute to undermining public confidence in the judiciary.

Support staff Similar to physical infrastructure, adequate support staff are essential to enable judges to fulfil their responsibilities. Judges are but one part of a larger bureaucratic system and are dependent upon others to assist them in the performance of their duties (Croatia, India, Portugal). Once again, public confidence is at stake.

Another aspect of the support staff issue is raised by the increasing demands that are put on judges in some jurisdictions to become administrators and managers in pursuit of greater effectiveness and efficiency. This can lead to questions being raised as to whether such judges do, in fact, have the requisite skills to fulfil such responsibilities (England and Wales, Portugal). 
Technological needs/supports Technological support is becoming an increasingly high-profile issue. ${ }^{73}$ The combination of demands by governments for increased efficiency, coupled with greater technological capacity on the part of many users of judicial services, has made technological competency, training and support an important aspect of contemporary judicial regulation (Croatia, India, New Zealand, Portugal). In part this is a resource issue; in part it is an education issue; in part it is a competence issue; and in part it may even be an appointments issue.

Security Although this is not an issue that is raised by many of the contributors, it is a concern for many judges in various parts of the world. ${ }^{74}$ Threats to physical safety can impair the impartiality and independence of individual judges and destabilize public confidence in the judiciary as an institution.

\section{iv. Outcomes}

As we indicated in Section II, the values that a jurisdiction chooses to prioritize, the processes it constructs and the resources it allocates are all targeted to achieving some outcome, some public good. In the development of their analyses or in their proposals for reform, all the contributors seem to agree that public confidence in the judiciary can serve as a highly generalized aspiration.

However, like the 'reasonable person' standard that is so pervasive in common law legal reasoning, the 'public confidence in the judiciary' standard has its own challenges. Collectively, the chapters in this collection suggest a number of insights.

First, one way to think about public confidence is to inquire whether, when it comes to controversial decisions, the judiciary receives high ratings from the general public. There is some support for this approach in several jurisdictions (India, Ireland, Japan, Portugal). The strength of this approach is that it indicates that judges are in touch with the dominant value structures of their community. The obvious weaknesses are the danger of majoritarianism, and concerns about impartiality and independence.

A second approach is to stand back a little from specific decisions, and to ask whether generally speaking the judiciary generates public confidence. Often this can be facilitated through a number of empirical instruments including trust in the professions polls, ${ }^{75}$ justice indexes ${ }^{76}$ or anti-corruption reports. ${ }^{77}$ Several of the chapters make reference to these indicators to some degree (Canada, Croatia, Ireland, Malaysia, Russia, Singapore). Such instruments are very helpful because they reveal perceptions not only from within a jurisdiction, but also from 
without. However, like most quantitative studies, they can only reveal so much.

A third perspective on public confidence that manifests itself in this collection is somewhat more amorphous, but at the same time more deepseated. It is the question whether judges are considered to be pursuing a public trust; whether they are fulfilling their part of the social contract with society that in return for permitting them to exercise significant sometimes even enormous - power and authority, they are doing so in the public interest. The essence of this approach is that the judges are competent and efficient in delivering impartial justice. Again a number of chapters reflect this theme, including those on Australia, England and Wales, and Singapore. The strength of this approach is that it captures the particular, essentially fiduciary, nature of the role of judges in the body politic. The weakness is its manifest indeterminacy.

However, this leads to a fourth insight generated by this collection, that is, public confidence has an almost alchemical quality. By this we mean that no one element can determine the existence, extent or intensity of public confidence in the judiciary. Rather, it seems that it is a complex combination of elements that fosters public confidence. Not only is public confidence dependent upon the mix of processes developed for the regulation of judges and the resources allocated to support those processes, it is also contingent upon the values that are embraced by a particular jurisdiction. Moreover, because, as we have seen, these values can vary from jurisdiction to jurisdiction, the elements that constitute public confidence can also vary from jurisdiction to jurisdiction. This means that careful attention needs to be paid to the larger social, economic, cultural, political and normative context in which each judiciary is located, and that there are no easy 'off the shelf' formulas that can guarantee public confidence.

Fifth, and finally, many of the chapters indicate that public confidence does not remain stable. As social values shift, so too do the determinants of public confidence (Australia, Canada, Croatia, England and Wales, Ireland). What might nurture and reinforce public confidence at one moment in the history of a particular jurisdiction may no longer be appropriate or sufficient at a later moment. Local, regional and global dynamics are in a constant state of flux and public confidence is protean. This means that those who are responsible for the regulation of judges need to be aware of and responsive to changing social values, and flexible and imaginative in reworking the compound. 


\section{JUDGES AND REGULATORY THEORY}

Finally we suggest that this collection demonstrates each of the five major themes of regulatory theory which we identified in Section II of this Introduction.

\section{A. Regulation Is an Inherently Normative and Programmatic Exercise}

Our contributors have identified various norms that inform current regulatory mechanisms or drive the desire for reform. As the foregoing discussion of public confidence in the judiciary vividly illustrates, regulation is about a great deal more than improving processes or the efficient allocation of resources - it is about the construction of the good society, and the expectations of judges in such a society. This requires the careful calibration of a number of values. Judicial regulation is part of the art of statecraft.

\section{B. Regulation Is Complex}

Every contributor has identified that the regulation of judges is a highly complex phenomenon with multiple moving parts. Many have also emphasized the interplay of both formal and informal dynamics and the differences between the status and functions of the judiciary on paper, compared to the reality on the ground.

Complexity has also led the contributors to identify a number of paradoxes. In Singapore, even though there is no public code of conduct, there is high public confidence. In Russia, despite the fact that courts are relatively accessible, affordable and efficient, that increasing numbers of people are utilizing the courts and that citizens are having significant success in suing their government, public confidence is low. In England and Wales, despite the justification for moving to a more open and inclusive system of appointments, the desired goal of increased diversity has failed to materialize. In China, despite the hegemony of the Communist party, in response to both local and international norms, there is a relatively well-functioning judiciary. In New Zealand there are monumental formal changes, but it remains to be seen if there will be much actual change.

\section{Regulatory Analysis Is Highly Contextual}

Any regulatory analysis of the judiciary must appreciate the particular contexts in which judiciaries operate and the unique responsibilities of 
judges. However, that uniqueness does not translate into a 'regulation-free' zone either descriptively or normatively. It would be a serious mistake to ignore the practices and insights from regulation in other fields; doing so may threaten the very outcomes that the judiciary is intended to achieve. Instead, those lessons should be considered in light of the specific contextual variables of the judiciary. Our contributors have shown that such variables can be traditional and cultural, but they can also be driven by global or regional dynamics. Other contextual variables may relate to the power or status of the judiciary within society and its ability to retain existing regulatory structures and resist external calls for reform.

\section{Hybridity Is the Leitmotif of Regulation}

No judicial system has opted for a singular regulatory regime. Rather, to varying degrees, they have deployed a complex matrix of regulatory mechanisms that often overlap, intersect and intertwine. Multiple actors are involved. Most systems have elements of self-, collaborative and external regulation. This can, of course, lead to tensions, contradictions and challenges, but it can also lead to more effective regimes.

\section{E. Change, Flux and Innovation}

The metaphor of a regulatory pyramid has been deployed to identify the multiplicity of variables in play in the regulation of judges, and to emphasize their interconnectedness and interdependence. All of the contributors have argued that each jurisdiction has experienced significant changes and challenges, some of which are quite radical. They also suggest that changes in one aspect of the regime can have an impact on other parts.

One particularly significant theme is the contrast between jurisdictions where there has been significant openness to change and others where there has been resistance. Examples of the former are Brazil, China, England and Wales, New Zealand and South Africa, while examples of the latter are Australia, Canada, Israel, Italy and Russia. Whether one agrees or disagrees with reform initiatives will inevitably depend upon the values one endorses and the outcomes sought.

\section{CONCLUSION}

To conclude, this collection of essays makes four key points. First, while the very idea of 'regulating judges' might irritate some people (especially some judges), the contributors confirm that the judiciary is 
highly regulated both as individuals and as an institution. Second, given this reality, the focus of our energy should shift from debating whether to regulate judges, to addressing the best practices and processes for the regulation of judges to ensure that they fulfil the public trust. This involves assessing the myriad of ways in which judges are in fact regulated and analysing and evaluating the extent to which different regulatory sub-regimes advance or impede desired regulatory outcomes. Third, there is a tendency in most jurisdictions to believe that the regulatory regime currently in place tends to approximate the ideal, and that change is risky, even dangerous. However, this book suggests that change is inevitable, that there are multiple regulatory options, and that good judicial governance is a constant work in progress. Fourth, our proposed regulatory pyramid can serve as a helpful (if necessarily imperfect) heuristic for description, analysis, assessment and critique as we pursue the improved regulation of judiciaries around the world.

\section{NOTES}

1. See eg Neal Tate and Torbjon Vallender (eds), The Global Expansion of Judicial Power (New York University Press 1995); Kate Malleson, The New Judiciary: The Effects of Expansionism and Activism (Ashgate 1999); Carlo Guarnieri and Patrizia Pederzoli, The Power of Judges: A Comparative Study of Courts and Democracy (Oxford University Press 2002); S Gloppen, B Wilson, R Gargarella, M Kinander and E Skaar, Courts and Power in Latin America and Africa (Palgrave Macmillan 2010); Diana Kapiszewski, Gordon Silverstein and Robert A Kagan (eds), Consequential Courts: Judicial Roles in Global Perspective (Cambridge University Press 2013).

2. See eg Daniel Klerman and Paul Mahoney, 'The Value of Judicial Independence: Evidence from Eighteenth Century England' (2005) 7 American Law and Economics Review 1; Lars P Feld and Stefan Voigt, 'Economic Growth and Judicial Independence: Cross Country Evidence Using a New Set of Indicators' (2003) CESIFO Working Paper No $906<$ http://ssrn.com/abstract=395403> accessed 25 February 2016.

3. See eg Guy Canivet, Mads Andenas and Duncan Fairgrieve (eds), Independence, Accountability and the Judiciary (British Institute of International and Comparative Law 2006); Malcolm Feeley, Lucien Karpik and Terrance Halliday, Fighting for Political Freedom: Comparative Studies in the Legal Complex and Political Liberalism (Hart 2007); Aharon Barak, The Judge in a Democracy (Princeton University Press 2008); Albie Sachs, The Strange Alchemy of Life and Law (Oxford University Press 2011); Tom Bingham, The Business of Judging: Selected Essays and Speeches, 1985-89 (Oxford University Press 2000).

4. C Larkins, 'Judicial Independence and Democratization: A Theoretical and Conceptual Analysis’ (1996) 44 American Journal of Comparative Law 605.

5. Richard Mohr, 'Local Court Reforms and "Global” Law' (2007) 3 Utrecht LR 41.

6. See eg Michael Mandel, The Charter of Rights and the Legalization of Politics in Canada (2nd edn, Thompson 2004); Ran Hirschl, Towards Juristocracy: The Origins and Consequences of the New Constitutionalism (Harvard University Press 2007); Gerald Rosenberg, The Hollow Hope: Can Courts Bring About Social Change? (2nd edn, University of Chicago Press 2008).

7. See eg Carlo Guarnieri and Patrizia Pederzoli, The Power of Judges: A Comparative 
Study of Courts and Democracy (Oxford University Press 2002); Siri Gloppen, Roberto Gargarella and Elin Skaar (eds), Democratization and the Judiciary: the Accountability Function of Courts in a New Democracy (Frank Cass 2004); John Bell, Judiciaries within Europe: A Comparative Review (Cambridge University Press 2006); Daniela Piana, Judicial Accountabilities in the New Europe from Rule of Law to Quality of Justice (Ashgate 2010); HP Lee (ed), Judiciaries in Comparative Perspective (Cambridge University Press 2011); Anja Seibert-Fohr (ed), Judicial Independence in Transition (Springer 2012).

8. Not all the contributors to this book would self-describe as pragmatists, some might be boosters, others sceptics. However, they have all agreed to participate because they agree that a discussion of judicial regulation is warranted and potentially insightful.

9. See eg Shimon Shetreet, Judges on Trial: The Independence and Accountability of the English Judiciary (North Holland Publishing Company 1976); Roberts Stevens, The Independence of the Judiciary (Oxford University Press 1993); Martin L Friedland, A Place Apart: Judicial Independence and Accountability in Canada (Canadian Judicial Council 1995); Stephen Burbank and Barry Friedman, Judicial Independence at the Crossroads: An Interdisciplinary Approach (Sage 2002); Guarnieri and Pederzoli (n 7); Canivet (n 3); Gloppen et al (n 7); Andrew LeSueur, 'Developing Mechanisms for Judicial Accountability in the UK' (2004) 24 Legal Studies 73; Sanford Levinson, 'The Role of the Judge in the 21st Century: Identifying "Independence"' (2006) 86 BUL Rev 1297; Jack Beatson, 'Judicial Independence and Accountability: Pressures and Opportunities' (2008) Judicial Review 1; Nuno Garoupa and Tom Ginsberg, 'The Comparative Law and Economics of Judicial Councils' (2009) 27 Berkeley Journal of International Law 53; Philip Langbroek, 'Administering Court and Judges: Rethinking the Tension between Accountability and Independence of the Judiciary' (Inaugural lecture, Utrecht University, 20 October 2009); Daniela Piana, 'Beyond Judicial Independence: Rule of Law and Judicial Accountabilities in Assessing Democratic Quality' (2010) 9 Comparative Sociology 40; Lee (n 7); Shimon Shetreet and Christopher Forsyth (eds), The Culture of Judicial Independence: Conceptual Foundations and Practical Challenges (Martinus Nijhoff 2012); Seibert-Fohr (n 7); Shimon Shetreet and Sophie Turenne, Judges on Trial: The Independence and Accountability of the English Judiciary (2nd edn, Cambridge University Press 2013).

10. See also Gloppen et al (n 1); Vicki Jackson, 'Judicial Independence: Structure, Context, Attitude' in Seibert-Fohr (n 7).

11. John Braithwaite, Cary Conglianese and David Levi-Faur, 'Can Regulation and Governance Make a Difference' (2007) 1(1) Regulation and Governance 1; Robert Baldwin, Martin Cave and Martin Lodge (eds), The Oxford Handbook of Regulation (Oxford University Press 2010).

12. See generally the journal Regulation and Governance.

13. Hugh Collins, Regulating Contracts (Oxford University Press 2002).

14. Neil Gunningham and Peter Grabosky, Smart Regulation: Designing Environmental Policy (Oxford University Press 1998).

15. Mark Findley and Wei Lim, Regulatory Worlds: Cultural and Social Perspectives when North Meets South (Edward Elgar Publishing 2014).

16. Christopher Hood and Martin Lodge, 'Pavlovian Innovation, Pet Solutions and Economizing on Rationality: Politicians and Dangerous Dogs' in Julia Black, Martin Lodge and Mark Thatcher (eds), Regulatory Innovation: A Comparative Analysis (Edward Elgar Publishing 2005).

17. See eg Jacinth Jordana and David Levi-Faur (eds), The Politics of Regulation: Institutions and Regulatory Reforms for the Age of Government (Edward Elgar Publishing 2005); GB Doern, MJ Prince and RJ Schulz, Rules and Unruliness: Canadian Regulatory Democracy, Governance, Capitalism and Welfarism (McGill-Queens University Press 2014).

18. John Braithwaite and Peter Drahos, Global Business Regulation (Cambridge University Press 2000). 
19. WB Gallie, 'Essentially Contested Concepts' (1956) 56 Proceedings of the Aristotelian Society 167.

20. Black et al, Regulatory Innovation (n 16).

21. Baldwin et al (n 11); Jordana and Levi-Faur (n 17).

22. Braithwaite et al (n 11); Christine Parker, 'Twenty Years of Responsive Regulation: An Appreciation and Appraisal' (2013) 7 Regulation and Governance 2.

23. Baldwin et al (n 11).

24. Ian Ayres and John Braithwaite, Responsive Regulation: Transcending the Deregulation Debate (Oxford University Press 1992).

25. Gunningham and Grabosky (n 14).

26. Christine Parker, The Open Corporation: Effective Self-Regulation and Democracy (Cambridge University Press 2002).

27. Robert Baldwin and Julia Black, 'Really Responsive Regulation' (2008) 71 Modern L Rev 59.

28. Bridget Hutter, The Attractions of Risk-Based Regulation: Accounting for the Emergence of Risk Ideas in Regulation (ESRC Centre for Analysis of Risk and Regulation 2005).

29. Christie Ford, 'Principles-Based Securities Regulation in the Wake of the Global Financial Crisis' (2010) 55 McGill L Rev 257.

30. Andrew Hopper and Gregory Treverton-Jones, Outcomes-Focused Regulation: A Practical Guide (Law Society 2011).

31. Christine Parker and Viebieke Nielsen (eds), Explaining Compliance: Business Responses to Regulation (Edward Elgar Publishing 2011).

32. Ayres and Braithwaite (n 24); Robert Baldwin, Martin Cave and Martin Lodge, Understanding Regulation: Theory, Strategy and Practice (2nd edn, Oxford University Press 2011).

33. Jordana and Levi-Faur (n 17).

34. Parker and Nielsen (n 31).

35. Malcolm Sparrow, The Regulatory Craft: Controlling Risks, Solving Problems and Managing Compliance (Brookings Institution Press 2000).

36. See eg Baldwin et al (n 11); Bärbel R Dorbeck-Jung, Mirjan, Oude Vrielink, Jordy F Gosselt, Joris J Van Hoof and Menno DT De Jong, 'Contested Hybridization of Regulation: Failure of the Dutch Regulatory System to Protect Minors from Harmful Media' (2010) 4(2) Regulation and Governance; David Levi-Faur (ed), Oxford Handbook of Governance (Oxford University Press 2012); Andrew Murray and Colin Scott, 'Controlling the New Media: Hybrid Responses to New Forms of Power' (2002) 65 Mod L Rev 491.

37. Baldwin and Black (n 27).

38. ibid.

39. Doern et al (n 17).

40. Ayres and Braithwaite (n 24).

41. David Osborne and Ted Gaebler, Reinventing Government: How the Entrepreneurial Spirit is Transforming the Public Sector (Plume 1993).

42. John Braithwaite and Christine Parker, 'Regulation' in Peter Cane and Mark Tushnet (eds), The Oxford Handbook of Legal Studies (Oxford University Press 2004).

43. See eg Ayres and Braithwaite (n 24); Jordana and Levi-Faur (n 17); Baldwin et al (n 32).

44. Julia Black, 'Learning from Regulatory Disasters' (2014) 10(3) Policy Quarterly 3.

45. Black et al (n 20).

46. In this book, we focus on national-level judiciaries. There are, of course, regional and international judiciaries such as the European Court of Justice or the International Criminal Court. We believe that the regulatory pyramid may also have resonance for such courts, but we have deliberately decided not to pursue that project in this volume of essays.

47. JuriGlobe World Legal Systems Research Group, 'Alphabetical Index of 192 United Nations Member States and Corresponding Legal Systems' (no date) <www.juriglobe. ca/eng/syst-onu/index-alpha.php> accessed 21 February 2016. 
48. See eg Kimberle Crenshaw, 'Mapping the Margins: Intersectionality, Identity Politics, and Violence Against Women of Color' (1991) 43(6) Standard L Rev 1241; Bruce MacDougall, 'The Direct Voice in Legal Discussions on Equality: An Essay' (2011) 44(1) UBC L Rev 181; Kimberle Crenshaw, On Intersectionality: Essential Writings (Perseus Distribution Services 2012).

49. See eg Parker (n 22).

50. See also Daniela Piana, Judicial Accountabilities in the New Europe: From Rule of Law to Quality of Justice (Ashgate 2010).

51. See also Wim Voermans, 'Judicial Transparency Furthering Public Accountability for New Judiciaries' (2007) 3(1) Utrecht LR 148; D Broeders, C Prins, H Griffioen, P Jonkers, M Bokhorst and M Sax (eds.) et al, Scope For A More Transparent Justice System (Amsterdam University Press 2013).

52. The Ethics in Government Act of 1978 (2006) 5 USC app 4 ss 101-11.

53. Council of Europe, Resolution (2002) 12 (18 September 2002).

54. ibid.

55. See also Richard Schauffler, 'Judicial Accountability in the US State Courts: Measuring Court Performance' (2007) 3(1) Utrecht LR 112.

56. See also Shetreet and Turenne (n 9) 5-10.

57. See generally Michael J Trebilcock and Barry J Reiter, 'Licensure in Law' in R Evans and M Trebilcock (eds), Lawyers and the Consumer Interest (Butterworths 1982).

58. See also Livingston Armytage, Educating Judges: Towards Improving Justice: A Survey of Global Practice (Brill 2015).

59. See also Richard Devlin, C Adèle Kent and Susan Lightstone, 'The Past, Present . . a and Future (?) of Judicial Ethics Education in Canada' (2013) 16(1) Legal Ethics 1.

60. See eg G Sykes (ed), Courting The Media: Contemporary Perspectives On Media And Law (Nova 2010); Ragna Aarli, 'Independent Judges and their Relationship with the Media' in Nils Engstad, Astrid Laerdal Froseth and Bard Tonder (eds), The Independence of Judges (Eleven International Publishing 2014) 327.

61. See eg Dahlia Lithwick, 'The Souter Factor: What Makes Tough Conservative Judges Go Soft?', Slate (3 August 3005) <www.slate.com/articles/news_and_politics/jurispru dence/2005/08/the_souter_factor.html> accessed 21 February 2016.

62. WS Hodge, 'The Citadel of Judicial Immunity' [1978] NZLJ 207; Shetreet and Turenne (n 9) 5 .

63. See further A Olowofoyeku, Suing Judges: A Study Of Judicial Immunity (Clarendon Press 1993).

64. See more generally, Francesci Contini, Sharyn Roach Anleu and David Rottman, 'Evaluating Judicial Performance: Editors' Introduction' (2014) 4 Oñati Socio-Legal Series 836.

65. See also Richard Mohr and F Contini, 'Judicial Evaluation in Context: Principles, Practices and Promise in Nine European Countries’ (2007) 1 European Journal of Legal Studies 1.

66. Richard Mohr and F Contini, 'Conflicts and Commonalities in Judicial Evaluation' (2014) 4(5) Oñati Socio-Legal Studies 843.

67. See eg Yohah Jeremy Bob, 'Bar Association Publishes 1st Survey on Judges in 10 Years', Jerusalem Post (Jerusalem, 12 January 2015) <www.jpost.com/Israel-News/ Bar-Association-publishes-1st-survey-on-judges-in-10-years-387486> accessed 1 March 2016; Doron Barzilay, 'Judicial Evaluation 2014 - An Essential Tool to Strengthen the Judiciary and Restore Public Trust', The Jerusalem Post (Jerusalem, 14 December 2014) $<$ www.jpost.com/Opinion/Judicial-Evaluation-2014-an-essential-tool-to-strengthenthe-judiciary-and-restore-public-trust-384625> accessed 21 February 2016.

68. Troy Riddell, Lori Hausegger and Matthew Hennigar, 'Evaluating Federally Appointed Judges in Canada: Analyzing the Controversy' (2012) 50 Osgoode Hall LJ 403.

69. RW Berch and EN Bass, 'Judicial Performance Review in Arizona: A Critical Assessment' (2014) 4(5) Oñati Socio-Legal Studies 927. 
70. M Warren, 'From Evaluation to Improvement: A Chief Justice's Perspective' (2014) 4(5) Oñati Socio-Legal Series 953.

71. See eg Carl Baar and Perry S Millar, Judicial Administration in Canada (McGill-Queen's Press 1981); Carl Baar, 'Judicial Independence and Judicial Administration: The Case of Provincial Court Judges' (1998) 9(4) Constitutional Forum 114; A Hol and P Langbroek, 'Adjudication in a Globalizing Context' (2007) 3 Utrecht LR 1.

72. See eg M Fabri and PM Langbroek, The Challenge of Change for European Judicial Systems: Developing a Public Administration Perspective (IOS Press 2000); K Benyekhlef, C Iavarone-Turcotte and N Vermeys, Comparative Analysis of Key Characteristics of Court Administration Systems (Canadian Judicial Council 2011).

73. See also Marco Velicogna, 'Justice Systems and ICT: What Can Be Learned from Europe?' (2007) 3(1) Utrecht LR 129.

74. See eg DK Tatlow, 'More Judges Are Seeking a Way Out', Globe and Mail (23 April 2015).

75. See eg IPSOS MORI, 'Trust in Professions' (5 January 2015).

76. World Justice Project, WJP Rule of Law Index 2015 (2015); European Commission, The 2015 EU Justice Scoreboard (European Union 2015).

77. European Commission, EU Anti-corruption Report 2014 (European Union 2014). 